\section{Birlesik Dúnya Arastrma Cypriot Journal of Educational BD-CENTER \\ Sciences}

Innovasyon ve Yayıneılık Merkezi
Volume 15, Issue 4, (2020) 766-776

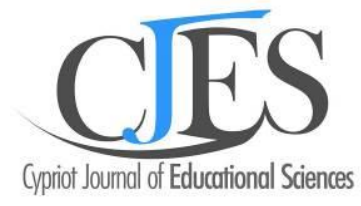

$\underline{\text { www.cjes.eu }}$

\title{
A teaching based technology in geography learning
}

Edi Kurniawan*, Universitas Negeri Semarang, Faculty of Social Science, Department of Geography, 50229, Semarang City, Indonesia https://orcid.org/0000-0002-8394-9259

Banowati Eva, Universitas Negeri Semarang, Faculty of Social Science, Department of Geography, 50229, Semarang City, Indonesia, https://orcid.org/0000-0002-7012-1778

Muchamad Dafip, Kognisi Foundation, Educational Research and Development, 50229, Semarang City, Indonesia, https://orcid.org/0000-0001-8059-8193

Sriyanto S, Universitas Negeri Semarang, Faculty of Social Science, Department of Geography, 50229, Semarang City, Indonesia https://orcid.org/0000-0002-5544-7390

\section{Suggested Citation:}

Kurniawan E, Eva B, Dafip M, and Sriyanto S. (2020). A Teaching Based Technology in Geography Learning. Cypriot Journal of Educational Science. 15(4), 766-776. DOI: 10.18844/cjes.v\%vi\%i.5058

Received 29 Juli 2020; revised 04 Agugust 2020; accepted from; accepted August 26, 2020.

(C)2020 Birlesik Dunya Yenilik Arastirma ve Yayincilik Merkezi. All rights reserved.

\section{Abstract}

This study aims to identify the ability of teachers to use technology and teacher competencies towards technology-based learning processes. This research involved 35 high school geography teachers in Semarang City. Variables analyzed include technological skill (TS); pedagogic competence (PED); professional competence (PRO); and technology-based learning (TBT) developed by teachers. The questionnaire was used in this research was closed questionnaire model. The collected data was tabulated and continued with Kolmogorov-Smirnov test, ANOVA test, Pearson correlation test and regression test. Based on the result, teacher's capability in using technology, has no connection with the technology-based learning that designed by them. While professional competency has no significant impact on the implementation of TBT $(p=0.801)$, with a partial negative value and R2 of only 4\%. It can be assumed that the technology-based learning was conducted based more on the ability of teachers to manage class and learning, rather than developing learning technology. Technology-based geography learning compiled by respondents is based more on the ability to manage classrooms and learning rather than developing learning technology. Based on the result, we recoment to stakeholders to facilitate teacher by providing technology training, instruments before moving to technology based teaching, and socialization.

Keywords : pedagogic competence, teaching technology, technology skill

\footnotetext{
* ADDRESS FOR CORRESPONDENCE: Edi Kurniawan, Universitas Negeri Semarang, Faculty of Social Science, Department of Geography, 50229, Semarang City, Indonesia

E-mail Address: edikurniawan@mail.unnes.ac.id
} 
Kurniawan E, Eva B, Dafip M, and Sriyanto S. (2020). A Teaching Based Technology in Geography Learning. Cypriot Journal of Educational Science. 15(4), 766-776. DOI: 10.18844/cjes.v\%vi\%i.5058

\section{Introduction}

Technological developments have metamorphosed not only in the hardware but also development of the cognitive computing in the way of information management (M. Chen, Herrera, \& Hwang, 2018). Technological development affects various activities, one of which is in the education sector. It is because the education sector is evolving in line with human developments (Stracke et al., 2017), including the technology implementation. Fast technological developments, manifested in devices that are very commonly used, such as smartphones and the internet. Based on data from the International Data Corporation (IDC), in 2017, smartphone users in Indonesia are estimated to reach 62.69 million people and predicted to increase by $33 \%$ in 2022 . In addition, smartphone users and internet access are interrelated, Google which provides the largest search engine in the world and most often used in Indonesia is very useful to be developed as a learning instrument.

The influence of technology on education sector, improves quality, strategies, assessments, and learning models that are in accordance with supported competencies (Sung, Chang, \& Liu, 2016) as well as students and teachers (Bond \& Bedenlier, 2019; Briz-Ponce, Pereira, Carvalho, Juanes-Méndez, \& García-Peñalvo, 2017; Habes, Salloum, Alghizzawi, \& Motteh, 2018). This step can increase participant's participation in creative learning process (Fabian, Topping, \& Barron, 2016; Harris, AlBataineh, \& Al-Bataineh, 2016; Henriksen, Mehta, \& Rosenberg, 2019; Ndofirepi, Rambe, \& Dzansi, 2018). However, education in Indonesia addresses the challenge of examining the flow of information relating to understanding related to technology and its use.

Facts in the real field show that not all educators develop technology in the learning process. The learning tools compiled are still textual and rely on textbooks as learning resources. In fact, smartphones and internet provide a roaming area of information and are very challenging as a learning resource for students (B. Chen, Chang, Ouyang, \& Zhou, 2018; Chugh \& Ruhi, 2018; Lavrinenko, Arpentieva, \& Kassymova, 2019; Moghavvemi, Sulaiman, Jaafar, \& Kasem, 2018; Santoro, Vrontis, Thrassou, \& Dezi, 2018). Today, the technological development in learning is lack of attention, it can be caused by no standard instrument model based on technology and unreliable. In the other side, low material contents access using smartphones and the internet is also contribute in technological weak. This study aims to identify the ability of teachers to use technology and teacher competencies towards technology-based learning processes.

\section{Method}

The study was conducted with an exploratory observational method involving public and private high schools in the city of Semarang. The variables analyzed in this study include expertise related to using technology (TS), in this case smartphone and internet access in daily life; pedagogic competence (PED); professional competence (PRO); and technology-based learning (TBT) developed by teachers.

The population in this study were public and private high school teachers who joined in the Geography Subject Teachers' Consultative Team (MGMP) in Semarang City. A total of 35 respondents were involved in this study voluntarily. Each respondent was asked to fill out an online questionnaire that was accessed via Google form, without pressured. The questionnaire filled in using the Guttman scale closed questionnaire model, the assessment score used the lowest value 1 and highest 4 depending on teacher preferences based on experience and teaching habits. Each respondent was given unlimited time and freedom and without coercion in answering each statement. The questionnaire used in this study consisted of four parts: 1) identity and informed concern, 2) competency assessment of expertise in using technology with 16 statements in total, Chronbach's 
alpha 0.710); 3) assessment of pedagogical competence as much as 7 statements, Chronbach's alpha 0.876 ; 4 ) assessment of professional competence of 6 statements, Chronbach's alpha 0.876; and 5) implementation of technology-based learning that is measured based on 5 aspects, Chronbach's alpha 0.900. The five aspects used in technology-based learning assessment include aspects of planning, preparation of learning tools, implementation of learning, application of learning technology, and evaluation.

The collected data was then extracted and grouped based on parameters of gender, age and academic level of the teacher, and the status of the school where the teacher work. All data obtained were collected and proceeded to the coding, tabulation and screening stages. Data were then tested for normality using non-parametric analysis of the Shapiro-Wilk test, normal data continued with the $t$ test, while the non-normal data continued with the Kolmogorov-Smirnov test. To find out whether there is a variance equation between variables, ANOVA test between variables was performed. Correlation and the magnitude of the effect of each variable on other variables, performed by linear correlation test and regression test. All statistical analyses were performed using SPSS 23.0, while the presentation of processed data was carried out using Ms. Excel version 16.31 for Mac.

\section{Result}

Data collection that has been done to a total of 37 respondents Geography teachers in the city of Semarang shows that more than $50 \%$ are female teacher respondents and the majority are over 35 years old and come from public schools (Table 1). In addition, the majority of teachers are undergraduate students and have not yet taken up professional teacher or master education.

Table 1. Respondent information of Geography teacher in Semarang City

\begin{tabular}{lcc}
\hline \multicolumn{1}{c}{ Parameter } & Amount & $\%$ \\
\hline Gender & & \\
Female & 19 & 51.35 \\
Male & 18 & 48.65 \\
& & \\
Ages & & \\
$<35$ & 15 & 40.54 \\
$>35$ & 22 & 59.46 \\
& & \\
School & & \\
Private & 14 & 37.84 \\
State & 23 & 62.16 \\
& & \\
Education & & \\
Bachelor & 22 & 59.46 \\
Master & 15 & 40.54 \\
\hline
\end{tabular}

The results of the identification of learning competencies show that the average value for all competencies is above $60 \%$. This indicates that the teacher's understanding in building technologybased learning is quite high. Judging from the parameters of gender, age, school status and educational background of teachers showed that the four competencies did not have a significant difference $(p>0.050)$ (Figure 1a-d). 
Professional competence is the competency that has the highest value compared to other competencies, except for the parameters of the teacher's educational background. Based on gender, teacher professional competence reached $86.67 \%$ in female teachers and $80.90 \%$ in male teachers (Figure 1a). Female teachers also have high marks in pedagogic competence and build technologybased learning, most of which have made use of smartphones in the evaluation process through the Edmodo, Kahoot, Google Form and e-learning applications from the Ministry of Education and Culture. But the mastery of smartphone and internet technology further, is higher in male teachers, although it does not show any significant difference. This is likely because male teachers are more intense in using smartphone applications in their daily activities, but not too intensely using technology in the learning process. Based on observations and interviews, male teachers tend to do learning with interactive lecture models with Ms. Power Point, outdoor learning by utilizing learning media provided by schools such as maps and binoculars.

Based on age parameters, teachers who are more than 35 years old are also identified as having lower technological mastery than teachers who are less than 35 years old, but both pedagogic and professional grades are still on the same average grade. In addition, teachers who are less than 35 years old have the value of implementing higher technology-based learning. These findings indicate that young teachers may be more frequent and innovative in using technology as one of the learning instruments.
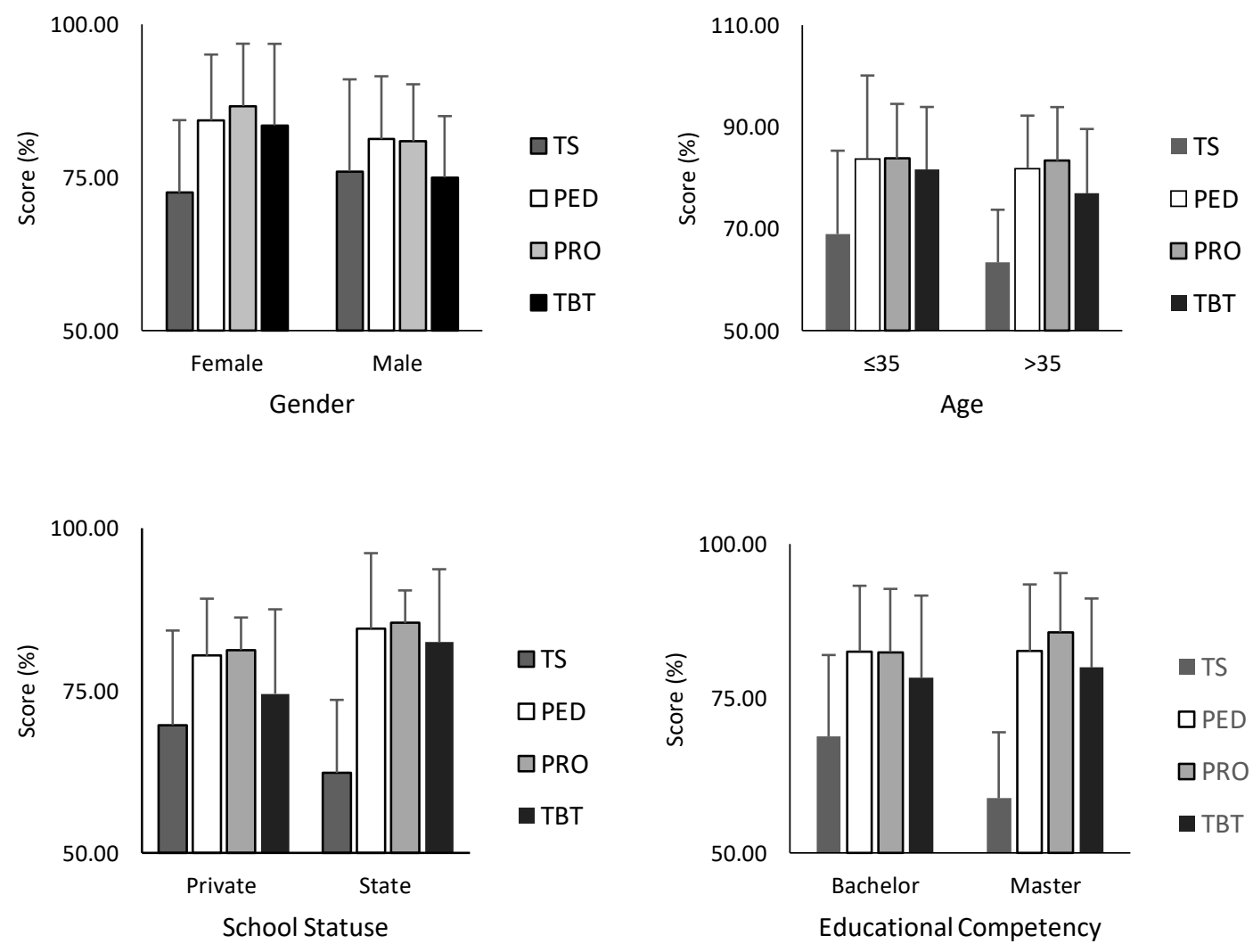

Figure 1. Competencies graphics of teacher of TS, PED, PRO and TBT in geography teachers in Semarang City. Grouping data to see differences in competency scores based on a) gender; b) age; c) school status; and d) educational competence. 
When viewed based on school status and teacher background, it appears that the ability to use technology tends to be lower in public schools and master's graduate teachers than private schools and graduate-level teachers. But for pedagogic competence and professionalism in both parameters have a high value. In addition, the technology-based learning process also has a high value, even higher than the value of the ability of teachers to use technology.

Some anomalies of the influence relationship between parameters found in this study, namely the TS value in all parameters is lower than the TBT value, whereas learning using technology must be supported by the teacher's ability to master technology. In addition, the analysis of the mean equation showed that the average TS values differed significantly with respect to the PED, PRO and TBT parameters $(p<0.050)$, while the PED and PRO parameter values were not significantly different from TBT $(p>0.050)$. Correlation analysis between parameters shows that the value of TS is not related to the PED, PRO and TBT values (Table 3). The possibility of anomaly is because, the use of learning applications controlled by respondents is an application that is routinely used and the menu choices that are used are limited based on habits in their use. This has an impact on the reliability of respondents in utilizing technology which is only limited to the application menu related to learning. Respondents tend to experience difficulties in developing applications and exploring content outside the learning features.

Table 3. Correlation among teacher's skill value

\begin{tabular}{lcccc}
\hline & TS & PED & PRO & TBT \\
\hline TS & 1 & 0.185 & 0.029 & 0.415 \\
PED & & 1 & $0.829^{* *}$ & $0.766^{* *}$ \\
PRO & \multicolumn{5}{c}{$0.581^{* *}$} \\
TBT & ${ }^{* *}$. Correlation is significant at the 0.01 level (2-tailed). & 1 \\
\hline \multicolumn{7}{r}{}
\end{tabular}

Data that has been through the testing of variance and correlation equations, then proceed to prove the relationship of the influence of correlation with regression testing. Regression testing begins with establishing a variable, where the TBT value is determined as the $Y$ variable (dependent variable) and TS, PED and PRO as the $X$ variable (independent variable). Meanwhile, based on regression analysis showed that the data had fulfilled the classical assumptions that included normal distribution data ( $p>0.05$ ), there was no multicollinearity (TIFF value $<10.00$ ) and showed no symptoms of heteroscedasticity $(p>0.05)$. based on the results of the classic assumption test shows that the data meet the requirements for regression analysis (Table 4).

Referring to the regression analysis, it shows that the TS value independently has no effect on the TBT value of geography teacher respondents. However, the implementation of TBT is related to pedagogical competence. The statistical findings further strengthen the results of the study that the ability of teachers to use technology, has no connection with technology-based learning by teachers. That is because the respondent's skill in using technology is only based on the habit of utilizing commonly used applications. Other findings in this study also indicate that despite having a relationship, professional competence does not have a significant impact on the implementation of TBT $(p=0.801)$, with a partial negative value and R2 of only $4 \%$. Teacher professional competence includes the teacher's knowledge about the field of science possessed. In this case, the development of technology-based geography learning fully utilizes learning materials that refer to the Ministry of Education and Culture's e-learning, therefore, teachers do not develop knowledge in the field of geographic science. 
Kurniawan E, Eva B, Dafip M, and Sriyanto S. (2020). A Teaching Based Technology in Geography Learning. Cypriot Journal of Educational Science. 15(4), 766-776. DOI: 10.18844/cjes.v\%vi\%i.5058

Table 4. Regression analysis among variables

\begin{tabular}{|c|c|c|c|c|c|c|c|c|}
\hline \multirow{3}{*}{ Variable } & \multicolumn{5}{|c|}{ Classical Assumption Test } & \multicolumn{3}{|c|}{ Hypothesis Test } \\
\hline & \multirow{2}{*}{$\begin{array}{l}\text { Normality test: } \\
\text { Kolmogorov-Smirnov }^{1}\end{array}$} & \multicolumn{2}{|c|}{ Multicollinearity } & \multicolumn{2}{|c|}{ Heteroscedasticity } & \multicolumn{2}{|c|}{ Effect } & \multirow{2}{*}{$\mathrm{R}^{2}$} \\
\hline & & Tolerant $\ddagger$ & $\mathrm{TIF}^{3}$ & Sig. ${ }^{4}$ & $\%$ & Sig $^{5}$ & Partial $^{6}$ & \\
\hline TS & 0.960 & 0.916 & 1.092 & 0.349 & 34.9 & 0.070 & 0.414 & 0.171 \\
\hline PED & 0.833 & 0.286 & 3.492 & 0.405 & 40.5 & 0.007 & 0.579 & 0.335 \\
\hline PRO & 0.388 & 0.296 & 3.375 & 0.259 & 25.9 & 0.801 & -0.060 & 0.004 \\
\hline TBT & 0.510 & Regressic & coeffi & nt of TS- & PRO to & ther to & d TBT up & 0.665 \\
\hline
\end{tabular}

Note : The symbol above row name indicates statistical analysis result. ${ }^{1)}$ normal distribution when $p>0.05$; $\ddagger$ there no multicollinearity data distribution when tolerant score $>0.100$ or ${ }^{3)}$ TIFF score $<10 ;{ }^{4)}$ No heteroscedasticity symptom when sig. value $>0.05$; Hypothesis test for regression, ${ }^{5)}$ significant correlation effect when sig. value $<0.05$ or ${ }^{6)}$ partial score $>0.500$.

Based on the results of interviews, limitations of facilities and infrastructure such as the absence of a geography laboratory also have an impact on the delivery of teacher scientific material. Respondents experienced problems in updating knowledge according to the development of science due to the limitations of learning tools and media. These problems make respondents more often convey learning based on the textbook, even though utilizing technology, the material presented is also contextual. In a number of state schools included in this research sample, informing students that the use of smartphone and internet technology is still very limited so that teachers also do not innovate learning using smartphones and the internet. This is done by the school, with the excuse of avoiding students from using smartphones outside the learning context, or opening social media and banned sites during the learning process.

\section{Discussion}

Empirically, this research is based on studies related to the readiness and quality of the geography teachers in facing technological developments. Previous research has evaluated the characteristics of pedagogic competence (Diep \& Hartmann, 2016; Ward \& Ayvazo, 2016), and professional teachers (Hanifah, Mohmadisa, Yazid, Nasir, \& Balkhis, 2019; Huda \& Teh, 2018; Ningrum, 2019) in general on the learning model. Previous research also put technological aspects as one of the free variables together with teacher competencies in the learning process that determines student achievement (Blau, Peled, \& Nusan, 2016). The facts found at the research location show that geography teachers have also used technology in this case are smartphones and the internet as one of the main instruments in learning. However, some school rules and teacher self-readiness are special notes on the implementation of technology-based learning models in the classroom. This research focuses on identifying in depth the extent of interaction between competencies in geography teachers, especially related to the ability to use technology, pedagogy and professionalism. An interesting finding in this study was the existence of an attitude of concern from the school regarding the use of smartphones, and the correlation anomaly between competencies and the results of the assessment of the implementation of technology used by teachers in learning geography in high schools in the city of Semarang.

It is inevitable that the increase in smartphone and internet users not only has a positive impact on the development of learning and information flow, but it also has negative side such as social media addiction (Carbonell, Chamarro, Oberst, Rodrigo, \& Prades, 2018) and pornography access (Rodda, Booth, Vacaru, Knaebe, \& Hodgins, 2018), hate speech, and crime (March \& Marrington, 2019). The 
case is likely caused by the use of smartphones that are not controlled, especially in adolescents. These worries make schools become insecure in issuing policies related to the use of smartphones by students. However, for example in some private high schools, smartphones may be brought in the classroom, but only used when learning is indeed in need. The harshest punishment related to violations of smartphone use is confiscation, and only returned at the end of the semester. Smartphones may be used in learning that does require a device both during the learning process and evaluation.

The competency standards and core competencies that students must achieve are basically determined by the ministry, but teachers are required to develop a learning process that is creative, effective, meaningful and fun. However, the problem of regulation about smartphone usage during learning process, limiting student to access the internet. In the other hand, low understanding in smartphones usage may influence teachers in developing learning model (Nelson, Voithofer, \& Cheng, 2019). It was reflected by the learning instruments that developed by the respondents, which majority of them did not clearly mention the application of the technology to expand material scope in geography subjects.

Constraints in the use of technology are usually solved by teachers by providing textbooks, handbooks and printed modules. Printed books are more preferable because it easier and comfortable to read, but limited information or not updated and too heavy (Ndihokubwayo \& Habiyaremye, 2018). It does not provide a guidance for student to find more information independently (Guo, Zimmer, Matthews, \& McTigue, 2019). In addition, conventional method makes difficulties in developing concept especially in geographical materials abstract such as continental plate formation and remote sensing. The conventional learning paradigm shows that teaching and learning process mostly conducted in classroom, then the teacher acts controlling over the course of learning (De Smet, De Wever, Schellens, \& Valcke, 2016) and limited interactive discussion (Allen, 2016; Bye, 2017; Farrell, 2016). In current situation, a teacher should be able to ack as a facilitator who facilitate their students accessing learning sources freely. Based on observations of the geography learning process, respondents use lecture methods on certain materials such as the basic concepts of geography and cooperative learning on other materials such as hydrosphere and lithosphere.

In pedagogical competence, respondents from both public and private high schools have a very high level of understanding, creativity and class management and have supported the use of technology in the learning process. The findings in this study indicate that pedagogic competence is very high, which is reflected in the ability of teachers to arrange the learning process. Respondents basically mastered learning theory and principles of learning that educate, set various approaches, strategies, methods, and learning techniques that educate creatively in accordance with teacher competency standards. Respondents in this study are also very capable of compiling syllabus in accordance with the most important objectives of the curriculum and using lesson plans in accordance with the objectives and learning environment, and are able to choose, compile, and organize learning materials that fit the needs of students. Respondents are very able to compile and implement learning designs that educate in full, carry out learning activities in accordance with the needs of students, as well as compile and use various learning materials and learning resources in accordance with the characteristics of students. Respondents also have utilized information communication technology (ICT) for learning purposes

Even so, there are some obstacles in managing class and students, too many students make it difficult to supervise (Irvin, Ingram, Huffman, Mason, \& Wills, 2018). Respondents find it difficult to supervise, take notes, and use information characteristic of students to help the learning process. These characteristics are related to the physical, intellectual, social, emotional, moral, and sociocultural aspects of students which actually need to be recorded to develop an appropriate learning 
system. The problem of supervision is also an obstacle faced by teachers in the smartphone and internet-based learning process. Basically, respondents have drawn up a learning plan wherein the portion and time of use of a smartphone are arranged in it. However, students who use smartphones and the internet not according to the learning objectives are still found. Supervision of these problems is still a chore for respondents. As a result, respondents are not free to use smartphones and internet as media and learning resources.

The professional competence has core components includes; 1) mastery of teaching materials, 2) Ability to manage learning materials, 3) applying evaluation of appropriate learning materials (Vladislavivna, 2019). These three aspects are a form of teacher's cognition in processing information, knowledge, and experience related to the field of science that they are involved in. In other words, the high value of professional competence reflects the teacher's confidence in the benefits and captures the moral message contained in every knowledge delivered. The value of professional competency obtained by respondents also shows a fairly high number, this indicates that the respondent mastered and delivered geographic material very well. However, based on an analysis of the effects between competencies, the ability of respondents to use technology is not related to professional competence. Furthermore, professional competence does not have a significant effect on technology-based learning by respondents. Even though the competency is directly related to the ability of students to understand geography. Nevertheless, both pedagogic values and professionalism have enormous interrelations and become a unity in formulating learning (Avidov-Ungar \& Forkosh-Baruch, 2018). This can be seen from the interaction of the three competencies that are able to influence TBT by more than $60 \%$.

The allegation that arises from these findings is the use of electronic media to make students more independent in gathering information or learning in inquiry. Or another possibility is the lack of measurement carried out in this study of the two competencies. Based on the results of the calculation of the correlation shows that professional parameters and the ability of teachers to use technology are not related. However, professional parameters correlate with the value of learning by the teacher. There needs to be a deeper study to identify factors or moderation beyond the measured competencies that are likely to have contributed to technological development. This research needs to be developed to describe each characteristic.

\section{Conclusion}

The average score for all respondents' competencies is above $60 \%$. This indicates that the understanding of teachers in developing technology-based learning is quite high, although there are no differences based on parameters of gender, age, school status and educational background ( $p>$ 0.050). Professional competence is the competency that has the highest value compared to other competencies, except for the parameters of the teacher's educational background. The ability to use technology and professional competence of teachers shows no correlation with the learning model that is built. Where the ability to use technology only contributes $17.1 \%$ and is not significant to the learning process and professional competence also does not have a significant impact on the implementation of TBT $(p=0.801)$, with a partial negative value and R2 which is only $4 \%$. Significant correlations and impacts were seen in the value of pedagogical competence on learning $(p=0,000)$. This indicates that technology-based geography learning compiled by respondents is based more on the ability to manage classrooms and learning rather than developing learning technology. 
Kurniawan E, Eva B, Dafip M, and Sriyanto S. (2020). A Teaching Based Technology in Geography Learning. Cypriot Journal of Educational Science. 15(4), 766-776. DOI: 10.18844/cjes.v\%vi\%i.5058

\section{Recommendation}

We found that, the respondent assumes that technology is not a crucial and urgent tool to be used for developing learning process. In several cases, the innovation in technology is not suitable with student or teacher skill and resources. Because of that problem, we recommend several issues, 1) it is needed an teaching based technology training to help teacher develop their skill and understanding about technology feature; 2) the school has to facilitate teacher by providing computer, internet resources and instruments before moving to technology based teaching; 3 ) the government can play a part by spreading out the internet connection and signal facilities to support teaching innovation. More over, socialization, providing technology acces (including internet and devices) and monitoring should be conduct to help student overcome their obstacle in technology based geography teaching.

\section{References}

Allen, D. (2016). The resourceful facilitator: Teacher leaders constructing identities as facilitators of teacher peer groups. Teachers and Teaching: Theory and Practice, 22(1), 70-83. https://doi.org/10.1080/13540602.2015.1023029

Avidov-Ungar, O., \& Forkosh-Baruch, A. (2018). Professional identity of teacher educators in the digital era in light of demands of pedagogical innovation. Teaching and Teacher Education, 73, 183-191. https://doi.org/10.1016/j.tate.2018.03.017

Blau, I., Peled, Y., \& Nusan, A. (2016). Technological, pedagogical and content knowledge in one-to-one classroom: teachers developing "digital wisdom." Interactive Learning Environments, 24(6), 1215-1230. https://doi.org/10.1080/10494820.2014.978792

Bond, M., \& Bedenlier, S. (2019). Facilitating student engagement through educational technology: Towards a conceptual framework. Journal of Interactive Media in Education, 2019(1), 1-14. https://doi.org/10.5334/jime.528

Briz-Ponce, L., Pereira, A., Carvalho, L., Juanes-Méndez, J. A., \& García-Peñalvo, F. J. (2017). Learning with mobile technologies - Students' behavior. Computers in Human Behavior, 72, 612-620. https://doi.org/10.1016/j.chb.2016.05.027

Bye, R. T. (2017). The teacher as a facilitator for learning: Flipped classroom in a master's course on artificial intelligence. CSEDU 2017 - Proceedings of the 9th International Conference on Computer Supported Education, 1(January), 184-195. https://doi.org/10.5220/0006378601840195

Carbonell, X., Chamarro, A., Oberst, U., Rodrigo, B., \& Prades, M. (2018). Problematic use of the internet and smartphones in university students: 2006-2017. International Journal of Environmental Research and Public Health, 15(3). https://doi.org/10.3390/ijerph15030475

Chen, B., Chang, Y. H., Ouyang, F., \& Zhou, W. (2018). Fostering student engagement in online discussion through social learning analytics. Internet and Higher Education, 37(December 2017), 21-30. https://doi.org/10.1016/j.iheduc.2017.12.002

Chen, M., Herrera, F., \& Hwang, K. (2018). Cognitive Computing: Architecture, Technologies and Intelligent Applications. IEEE Access, 6, 19774-19783. https://doi.org/10.1109/ACCESS.2018.2791469

Chugh, R., \& Ruhi, U. (2018). Social media in higher education: A literature review of Facebook. Education and Information Technologies, 23(2), 605-616. https://doi.org/10.1007/s10639-017-9621-2

De Smet, C., De Wever, B., Schellens, T., \& Valcke, M. (2016). Differential impact of learning path based versus conventional instruction in science education. Computers and Education, 99(October 2017), 53-67. https://doi.org/10.1016/j.compedu.2016.04.001

Diep, P. C., \& Hartmann, M. (2016). Green Skills in Vocational Teacher Education - a model of pedagogical competence for a world of sustainable development. TVET @ Asia@Asia, (6), 1-19. https://doi.org/10.1002/ISSN

Fabian, K., Topping, K. J., \& Barron, I. G. (2016). Mobile technology and mathematics: effects on students' attitudes, engagement, and achievement. Journal of Computers in Education, 3(1), 77-104. 
Kurniawan E, Eva B, Dafip M, and Sriyanto S. (2020). A Teaching Based Technology in Geography Learning. Cypriot Journal of Educational Science. 15(4), 766-776. DOI: 10.18844/cjes.v\%vi\%i.5058

https://doi.org/10.1007/s40692-015-0048-8

Farrell, T. S. C. (2016). The teacher is a facilitator: Reflecting on ESL teacher beliefs through metaphor analysis. Iranian Journal of Language Teaching Research, 4(1), 1-10. Retrieved from https://files.eric.ed.gov/fulltext/EJ1127419.pdf

Guo, D., Zimmer, W., Matthews, S. D., \& McTigue, E. M. (2019). Critical analysis of research on the impact of visual literacy for learning: strengths, weaknesses and recommendations for improvement. Journal of Visual Literacy, 38(3), 181-198. https://doi.org/10.1080/1051144X.2019.1611702

Habes, M., Salloum, S. A., Alghizzawi, M., \& Motteh, S. (2018). The role of modern media technology in improving collaborative learning of students in Jordanian universities. International Journal of Information Technology and Language Studies, 2, 71-82. Retrieved from https://journals.sfu.ca/ijitls/index.php/ijitls/article/view/51

Hanifah, M., Mohmadisa, H., Yazid, S., Nasir, N., \& Balkhis, N. S. (2019). Professional and pedagogical competencies of geography teachers in Malaysia. Review of International Geographical Education Online, 9(2), 304-318. https://doi.org/10.33403/rigeo.509836

Harris, J. L., Al-Bataineh, M. T., \& Al-Bataineh, A. (2016). One to One Technology and its Effect on Student Academic Achievement and Motivation. Contemporary Educational Technology, 7(4), 368-381.

Henriksen, D., Mehta, R., \& Rosenberg, J. M. (2019). Supporting a Creatively Focused Technology Fluent Mindset among Educators: A Five-Year Inquiry into Teachers' Confidence with Technology. Journal of Technology and Teacher Education, 27(1), 63-95. Retrieved from http://search.ebscohost.com/login.aspx?direct=true\&db=eric\&AN=EJ1216023\&site=ehostlive\%0Ahttps://www.learntechlib.org/primary/p/184724/

Huda, M., \& Teh, K. S. M. (2018). Empowering professional and ethical competence on reflective teaching practice in digital era. Mentorship Strategies in Teacher Education, (July), 136-152. https://doi.org/10.4018/978-1-5225-4050-2.ch007

Irvin, D. W., Ingram, P., Huffman, J., Mason, R., \& Wills, H. (2018). Exploring paraprofessional and classroom factors affecting teacher supervision. Research in Developmental Disabilities, 73(April 2017), 106-114. https://doi.org/10.1016/j.ridd.2017.12.013

Lavrinenko, S. V., Arpentieva, M. R., \& Kassymova, G. K. (2019). The negative impact of the internet on the educational process. AIP Conference Proceedings, 2135(August). https://doi.org/10.1063/1.5120671

March, E., \& Marrington, J. (2019). A Qualitative Analysis of Internet Trolling. Cyberpsychology, Behavior, and Social Networking, 22(3), 192-197. https://doi.org/10.1089/cyber.2018.0210

Moghavvemi, S., Sulaiman, A., Jaafar, N. I., \& Kasem, N. (2018). Social media as a complementary learning tool for teaching and learning: The case of youtube. International Journal of Management Education, 16(1), 3742. https://doi.org/10.1016/j.ijme.2017.12.001

Ndihokubwayo, K., \& Habiyaremye, H. T. (2018). Why did Rwanda shift from knowledge to competence based curriculum? Syllabuses and textbooks point of view. African Research Review, 12(3), 38. https://doi.org/10.4314/afrrev.v12i3.4

Ndofirepi, T. M., Rambe, P., \& Dzansi, D. Y. (2018). The relationship among technological creativity, self-efficacy and entrepreneurial intentions of selected South African university of technology students. Acta Commercii, 18(1), 1-14. https://doi.org/10.4102/ac.v18i1.544

Nelson, M. J., Voithofer, R., \& Cheng, S. L. (2019). Mediating factors that influence the technology integration practices of teacher educators. Computers and Education, 128(October 2018), 330-344. https://doi.org/10.1016/j.compedu.2018.09.023

Ningrum, E. (2019). Mapping of Pedagogic Competency of Geography Teacher in Scientific Learning Based-On Curriculum 2013. IOP Conference Series: Earth and Environmental Science, 286(1). https://doi.org/10.1088/1755-1315/286/1/012007

Rodda, S. N., Booth, N., Vacaru, M., Knaebe, B., \& Hodgins, D. C. (2018). Behaviour change strategies for internet, pornography and gaming addiction: A taxonomy and content analysis of professional and consumer websites. Computers in Human Behavior, 84, 467-476. https://doi.org/10.1016/j.chb.2018.03.021

Santoro, G., Vrontis, D., Thrassou, A., \& Dezi, L. (2018). The Internet of Things: Building a knowledge management system for open innovation and knowledge management capacity. Technological Forecasting 
Kurniawan E, Eva B, Dafip M, and Sriyanto S. (2020). A Teaching Based Technology in Geography Learning. Cypriot Journal of Educational Science. 15(4), 766-776. DOI: 10.18844/cjes.v\%vi\%i.5058

and Social Change, 136, 347-354. https://doi.org/10.1016/j.techfore.2017.02.034

Stracke, C. M., Kameas, A., Vassiliadis, B., Sgouropoulou, C., Teixeira, A. M., Do Carmo Pinto, M., \& Vidal, G. (2017). The quality of open online education: Towards a reference framework for MOOCs. IEEE Global Engineering Education Conference, EDUCON, (April), 1713-1716. https://doi.org/10.1109/EDUCON.2017.7943080

Sung, Y. T., Chang, K. E., \& Liu, T. C. (2016). The effects of integrating mobile devices with teaching and learning on students' learning performance: A meta-analysis and research synthesis. Computers and Education, 94, 252-275. https://doi.org/10.1016/j.compedu.2015.11.008

Vladislavivna, A.-L. L. (2019). The Essence and Specific Aspects of Pre-School Teachers Methodologikal Competence in The Professional Pedagogical Competence Structure. Balkan Scientific Review, 4(6), $26-48$. https://doi.org/10.36059/978-966-397-161-2/26-48

Ward, P., \& Ayvazo, S. (2016). Pedagogical content knowledge: Conceptions and findings in physical education. Journal of Teaching in Physical Education, 35(3), 194-207. https://doi.org/10.1123/jtpe.2016-0037 